\section{Rotary Hoe Cultivation in Sweet Corn}

\author{
Maryse L. Leblanc ${ }^{1}$, Daniel C. Cloutier ${ }^{2}$, and Katrine A. Stewart ${ }^{3}$
}

ADDITIONAL INDEX WORDs. cultivation, mechanical weeding, physical weed control, Zea mays

Summary. A 2-year study was conducted to assess sweet corn (Zea mays) susceptibility to mechanical weeding using a rotary hoe at preemergence to six-leaf stages of corn development and at different combinations of stages. Three sweet corn cultivars: early ('Quickie'), mid ('July Gem'), and late season ('Sensor') were seeded at two sowing dates. The experiment was conducted in a weed-free environment. In general, sweet corn could be cultivated with the rotary hoe at least once without yield reduction from preemergence to the six-leaf stage. Cob numbers were reduced and maturity delayed after three or four cultivations with the rotary hoe. The rotary hoe could be an effective tool in controlling weeds in an integrated weed management approach or for organic sweet corn production since it cultivates both within and between the rows. The rotary hoe, which covers a large area in a short time, can be used at later growth stages, extending the time period during which it can be used without damaging the crop and reducing yield.

S weet corn is the most commonly grown vegetable in Canada with Québec accounting for 33\% of Canada's total sweet corn area (Statistics Canada, 2004). Large quantities of herbicides are currently used in commercial production with $95 \%$ of the crop area receiving one to two applications per year. Sweet corn producers are under increased pressure to decrease herbicide usage in response to environmental concerns (Giroux, 2002). This situation coupled with an increased demand for pesticide-free crops has promoted an interest in the use of alternatives, such as mechanical weed control, in sweet corn management.

Smith et al. (1996) were able to control weeds with mechanical weeders in grain or fodder corn (Z. mays). Mechanical weeding of field corn usually requires two weeders; one to cultivate broadcast over the corn row and between the rows at the beginning of the season and a second cultivator

${ }^{1}$ Corresponding author. Institut de recherche et de développement en agroenvironnement, P.O. Box 480, Saint-Hyacinthe, Que., Canada J2S 7B8. E-mail: maryse.leblanc@irda.qc.ca

${ }^{2}$ Institut de malherbologie, P.O. Box 222, Ste-Annede-Bellevue, Que., Canada H9X 3R9.

${ }^{3}$ Department of Plant Sciences, McGill University, 21111 Lakeshore, Ste-Anne-de-Bellevue, Que., Canada H9X 3V9.

Acknowledgments. We thank Germain Moreau, summer students, and field personnel for their assistance.

“Ce projet a été réalisé dans le cadre du Programme agroenvironnemental de soutien à la Stratégie phytosanitaire avec une aide financière du Plan déaction Saint-Laurent, lequel est une entente de concertation Canada-Québec.” to weed between corn rows later in the season when the crop is more developed (Leblanc and Cloutier, 2001). Unfortunately, sweet corn has been reported to be more susceptible than grain corn to damage caused by intra-row cultivation (Colquhoun et al., 1999; Lareau, 1997). Inter-row weeding has been generally well mastered using cultivators (Cloutier and Leblanc, 2001; Colquhoun et al., 1999). However, selective intrarow weeding at the beginning of the growing season is more problematic. Weeds that become established during this period can cause considerable yield losses and therefore, intra- and interrow weeds must be removed as early as possible. One of the few weeders currently available that can perform this task is the rotary hoe. The rotary hoe can cultivate two to four times faster than a regular inter-row weeder and this implement is most effective when it is used on germinating weeds prior to emergence or at the cotyledon stage (Cloutier et al., 1996; Gunsolus, 1990). However, there is the possibility of damage to the crop since the rotary hoe cultivates on the row.

The primary objective of this proj- ect was to determine the susceptibility of various growth stages of sweet corn to physical damage caused by rotary hoe cultivation. Sweet corn is normally planted at different dates during the growing season to spread corn harvesting over weeks and cultivars have different growth and development characteristics. Therefore, different planting dates were also included in this project along with three cultivars to determine if differences in susceptibility existed between cultivars and/or different planting dates.

\section{Materials and methods}

Five field experiments were conducted both in 1999 and 2000 at the research station of the Institut de recherche et de développement en agroenvironnement, Saint-Hyacinthe, Québec, Canada. Three sweet corn cultivars: early ['Quickie', a heterozygous sugary enhanced (sesu) hybrid, 59 d to maturity], mid-season ['July Gem', a homozygous sugary enhanced (sese) hybrid, $69 \mathrm{~d}$ to maturity] and late-season ['Sensor', a homozygous sugary enhanced (sese) hybrid, $78 \mathrm{~d}$ to maturity] were used in the trials. A four-row John Deere Max Emerge2 7200 planter (Deere \& Co. Moline, Ill.) sowed the seeds $3 \mathrm{~cm}$ deep in 30 -inch rows at a density of 51,800 seeds/ha on 29 Apr. 1999 and 3 May 2000. The mid-season and the lateseason cultivar had a second sowing date on 20 May 1999 and 23 May 2000. In 1999, the soil used for the first and second seeding date was a Duravin loam (coarse-loamy over clayey, mixed, mesic, Typic Endoaquept). In 2000, the soil used for the first and second seeding date was a Duravin loam and a Dujour clay loam (fine clayey, mixed, mesic, Aeric Humaquept), respectively. Fields were fall plowed and spring harrowed and fertilized according to soil analysis and provincial recommendations (Conseil des Productions Végétales du Québec Inc., 1994). In order to prevent confounding with weed interference, this project was conducted in a weed-free

\begin{tabular}{llll}
\hline $\begin{array}{l}\text { Units } \\
\text { To convert U.S. to SI, } \\
\text { multiply by }\end{array}$ & U.S. unit & SI unit & $\begin{array}{l}\text { To convert SI to U.S., } \\
\text { multiply by }\end{array}$ \\
\hline 0.4047 & acre(s) & ha & 2.4711 \\
0.3048 & $\mathrm{ft}$ & $\mathrm{m}$ & 3.2808 \\
2.54 & inch(es $)$ & $\mathrm{cm}$ & 0.3937 \\
25.4 & inch(es) & $\mathrm{mm}$ & 0.0394 \\
1.1209 & $\mathrm{lb} / \mathrm{acre}$ & $\mathrm{kg} \cdot \mathrm{ha}^{-1}$ & 0.8922 \\
1.6093 & $\mathrm{mph}$ & $\mathrm{km} \cdot \mathrm{h}^{-1}$ & 0.6214
\end{tabular}


environment by treating the field with selective herbicides. Metolachlor and cyanazine were applied pre-emergence at rates of $1.92 \mathrm{~kg} \cdot \mathrm{ha}^{-1}$ a.i. and 1.80 $\mathrm{kg} \cdot \mathrm{ha}^{-1}$ a.i., respectively. Due to weed escapes, in the early-season cultivar, a post-emergence atrazine and corn oil was applied at rates of $1.44 \mathrm{~kg} \cdot \mathrm{ha}^{-1}$ a.i. and $1.25 \% \mathrm{v} / \mathrm{v}$, respectively.

The experimental design was a randomized complete block with four replications. Plots were $3 \mathrm{~m}$ wide (four rows) and $10 \mathrm{~m}$ long. Grain corn was planted around and between blocks to minimize edge effects. A distance of $20 \mathrm{~m}$ was left between blocks in order to enable the tractor to reach the proper operating speed when cultivating the plots. The rotary hoe used in this project was a high ground clearance model (3412) from Yetter (Yetter Manufacturing Co. Inc., Colchester, Ill.). The hoe was 3 $\mathrm{m}$ wide and the speed of operation was $15 \mathrm{~km} \cdot \mathrm{h}^{-1}$ and the working depth varied from 4 to $5 \mathrm{~cm}$. Treatments consisted of systematically cultivating every crop growth stage once, from pre-emergence $(\mathrm{L} 0=\mathrm{BBCH}-06)$ to the sixth-leaf stage (L6=BBCH-16) (Bleiholder et al., 1997) $[\mathrm{BBCH}$ = Biologische Bundesanstalt, Bundessortenamt and Chemische Industrie (German Federal Biological Research Centre for Agriculture and Forestry, German Federal Office of Plant Varieties, Chemical Industry)]. Other treatments involved combinations of cultivations at different growth stages. In addition, a non-cultivated control treatment was included. Five meters of row in the two center rows of each plot were harvested manually for yield data. In 1999, early, mid-season and late-season corn were harvested on 14, 21 , and 30 July, respectively, for the first seeding date. For the second seeding date, mid-season and late-season corn were harvested on 29 July and 10 Aug., respectively. In 2000, early, mid-season and late-season corn were harvested on 3,11 , and 18 Aug., respectively, for the first seeding date. For the second seeding date, mid-season corn was harvested on 16 Aug. The late-season corn in the second planting in 2000 was not harvested due to uneven crop emergence. At harvest, crop stand and cob number per hectare were recorded. Afterwards, cobs were husked and the percentage of non-marketable cobs determined based on cob maturity, disease and insect damage (Canadian
Food Inspection Agency, 1999). For marketable cobs, length, diameter, and length of the undeveloped cob tips were measured. Data were subjected to analysis of variance using SAS (version 6; SAS Institute Inc., Cary, N.C.) and tested for normality. Statistically, the different cultivars or planting dates could not be combined. Data were transformed when required using either square root or log transformations to attain homogeneity of variance. For clarity, untransformed data with SE of the mean are presented in the tables. Treatments were compared with orthogonal contrasts.

\section{Results and discussion}

EARLY-SEASON CULTIVAR. In 1999, the crop could be cultivated up to four times without a significant reduction in total yield compared with the non-cultivated control (Table 1). Seventy seven percent of the yield was marketable for plants cultivated up to three times, whereas four cultivations reduced the marketable cobs to $64.9 \%$ of the total yield. Control plants or those cultivated once had significantly greater marketable yields than plants cultivated four times. In 2000, no significant differences in crop stand, total and marketable yield were observed between the cultivation treatments and the control. Treatments cultivated two or three times had significantly lower crop stand, total and marketable yields than treatments cultivated once. As the number of cultivations increased the chance of damaging the crop also increased. A significant increase in marketable yield was recorded for plants cultivated at the six-leaf stage compared with other single cultivation treatments (Table 1). Cob diameter (41 $\mathrm{mm}$ ) was unaffected by rotary hoeing in both years (data not shown). In 1999, cobs were significantly longer when corn was cultivated once $(17.3 \mathrm{~cm})$, twice $(17.4 \mathrm{~cm})$ or three times $(17.6$ $\mathrm{cm})$ compared with the non-cultivated control (16.5 cm; Table 1). However, in 2000 , corn cultivated two or four times had 1.8 and $1.2 \%$ shorter cobs than the non-cultivated control (16.6 $\mathrm{cm}$ ) or treatments cultivated once ( 16.5 cm). In 1999, all cultivation treatments significantly reduced the length of the undeveloped cob tip (5.2\%) compared with the non-cultivated control (7.2\%). In 2000 , there was no significant difference among treatments with an overall mean of $8.3 \%$ of the cob length un- filled. This would make the sweet corn growth stage Ll the most susceptible to damage by cultivation. There was no significant difference among treatments in the percentage of cobs that were rejected due to insect damage, disease and lack of uniformity (data not shown). Cultivating the crop with the rotary hoe affected cob maturity and hence percentage cob rejection (Table 1). In 1999, a single cultivation at the Ll stage significantly increased the percentage of immature cobs compared with a single cultivation at any other stage of development. There was no difference when the crop was cultivated once or twice. However, there was a significant increase in the number of immature cobs at four cultivations (Table 1). The number of immature cobs in the non-cultivated control was significantly lower than that of plots cultivated four times. In 2000, there was no difference in the percentage of immature cobs between the single cultivation treatments and the control. Control plants had significantly less immature cobs than plots cultivated three or four times. A single cultivation with the rotary hoe regardless of the stage of development of the crops had significantly less immature cobs than all other cultivation treatments.

Mid-season cultivar. For the first seeding, total yield, for both years, was reduced by $21 \%, 26 \%$, and $50 \%$ in the treatments that received two, three, or four cultivations, respectively, compared with the non-cultivated control (Table 2). Crop stand in 2000 followed the same trend. Sweet corn cultivated once had marketable yields similar to those of the control. Otherwise, marketable yield followed a trend similar to that of total yield. In 1999 and 2000, there were no significant differences in cob diameter (45-47 mm; data not shown), and length $(17.7-19.2 \mathrm{~cm})$. In 1999, one, three, or four cultivations significantly reduced the length of the undeveloped cob tip compared with the control plants. In 2000, the control plants had more undeveloped cob length than those plants which had been cultivated four times. Among treatments, there was no significant difference in the number of immature cobs and in the number of cobs rejected due to disease, insect damage, or lack of uniformity (data not shown). Immature cobs accounted for the greatest percentage of rejection $(20 \%)$ (data not shown). 


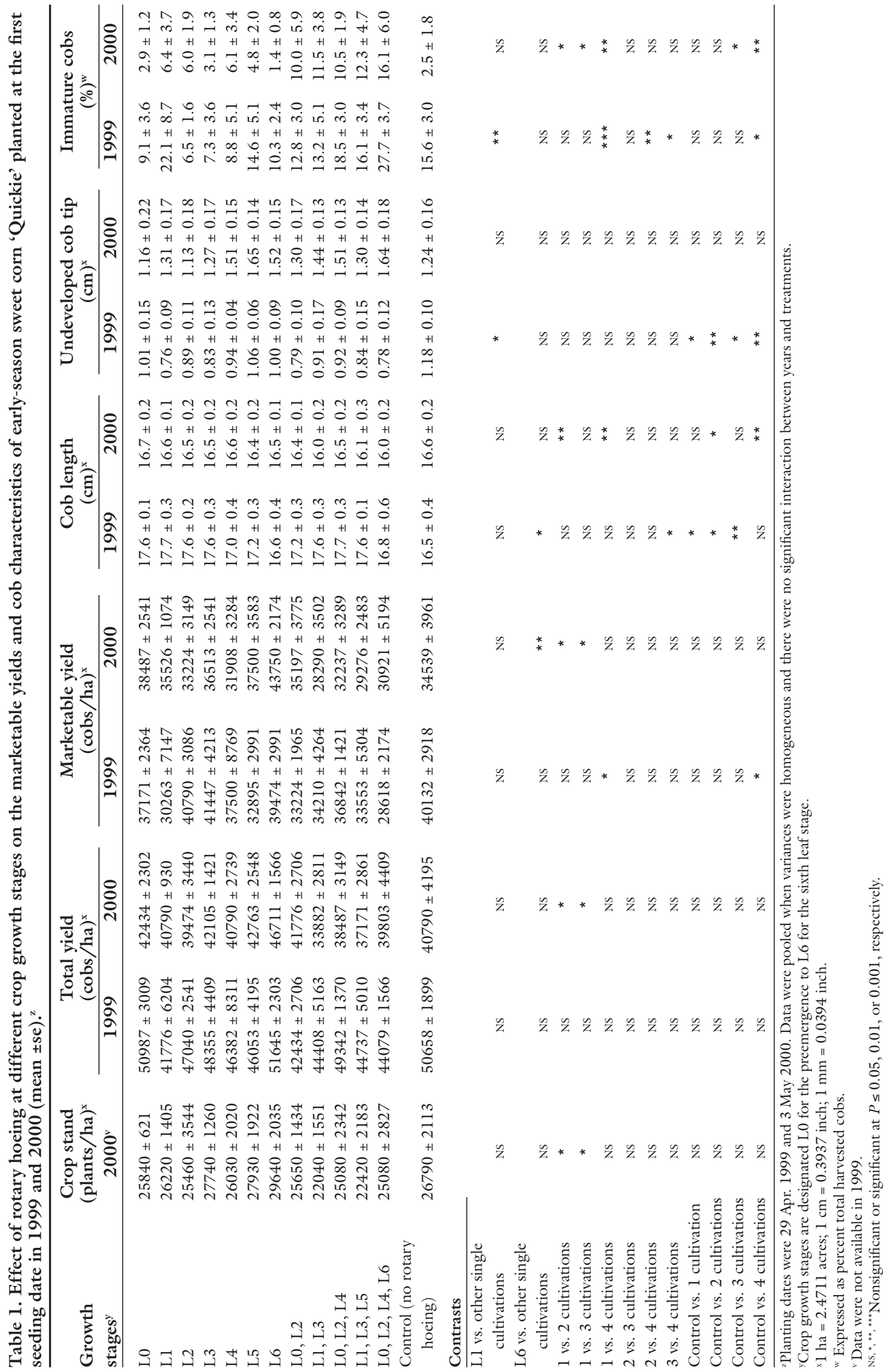


Table 2. Effect of rotary hoeing at different crop growth stages on the marketable yields and cob characteristics of mid-season sweet corn 'July Gem' planted at the first seeding date in 1999 and 2000 (mean \pm SE). ${ }^{\text {. }}$

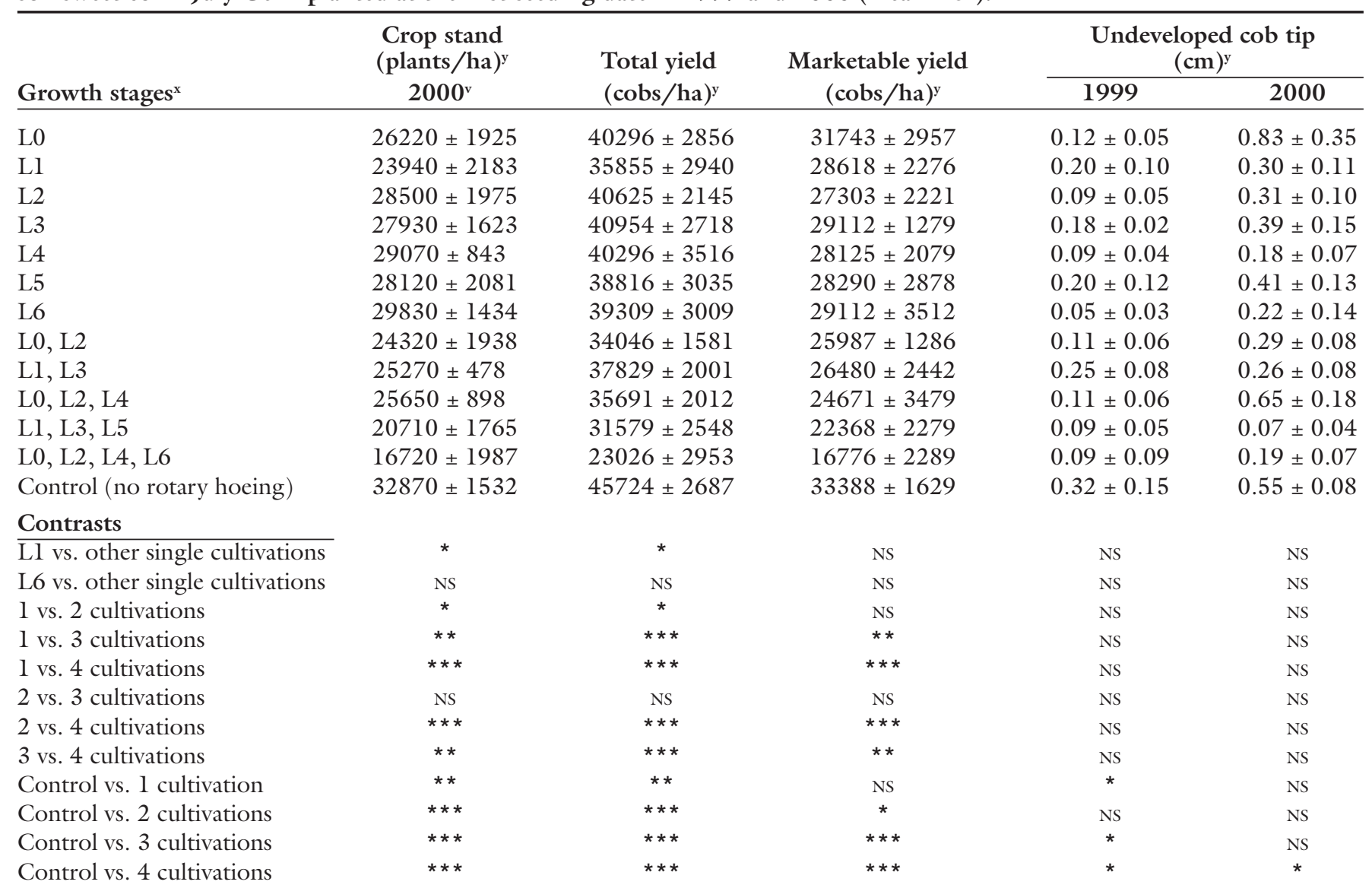

${ }^{2}$ Planting dates were 29 Apr. 1999 and 3 May 2000. Data were pooled when variances were homogeneous and there were no significant interaction between years and treatments.

$\mathrm{y} 1 \mathrm{ha}=2.4711$ acres; $1 \mathrm{~cm}=0.3937$ inch; $1 \mathrm{~mm}=0.0394$ inch

${ }^{\mathrm{s} C r o p}$ growth stages are designated L0 for the preemergence to L6 for the sixth-leaf stage.

wExpressed as percentage of total harvested cobs.

"Data were not available in 1999.

NS, ${ }^{*}{ }^{* *},{ }^{* \star}$ Nonsignificant or significant at $P \leq 0.05,0.01$, or 0.001 , respectively.

For the second seeding, four cultivations with the rotary hoe significantly decreased crop stand and total yield in both years (Table 3 ). Three or four cultivations decreased marketable yield between $13 \%$ and $44 \%$ compared with sweet corn cultivated once or non-cultivated. In 1999, cob diameter was significantly greater for corn cultivated four times $(44.7 \mathrm{~mm}$ ) than for all other treatments. In 2000, cob diameters of plants cultivated three times were significantly smaller than those of the control plants. In both years, cob length varied between 16.9 and $18.6 \mathrm{~cm}$ with no significant differences among treatments (data not shown). Cobs had in general less than $3 \%$ of the length undeveloped in 1999. In 2000, the undeveloped cob tip varied between $3.1 \%$ and $8.7 \%$ of the cob length. The undeveloped tip was shorter for corn cultivated four times $(3.1 \%)$ compared with the con- trol $(6.1 \%)$ and plots cultivated once $(5.8 \%)$ or three times $(7.0 \%)$. In both years, corn cultivated three $(30.8 \%)$ or four times $(35.3 \%)$ had a greater percentage of immature cobs than treatments cultivated once or twice (mean value $21.7 \%$ ).

Late-Season Cultivar. For the first seeding, in 1999, up to two cultivations did not significantly reduce total yield (Table 4). However, the marketable yield decreased as the number of cultivations increased, although differences were only significant between plants cultivated four times and those cultivated once or not at all. There was no difference among treatments in the percentage of yield that was marketable $(65 \%)$. In 2000 , two, three, or four cultivations reduced the percentage of the crop that was marketable and reduced yields by $42 \%, 47 \%$, and $49 \%$, respectively, compared with corn cultivated once or non-cultivated. In both years, corn cultivated four times had a cob diameter between $2 \%$ and $3 \%$ smaller than those with one $(41.4 \mathrm{~mm})$, two $(41.2$ $\mathrm{mm})$, or three $(41.2 \mathrm{~mm})$ cultivations. There were no significant differences in either cob length or undeveloped cob tip. Plots cultivated four times had significantly more immature cobs than those cultivated once. In 2000, either no cultivation or only a single cultivation resulted in fewer immature cobs than all other treatments. The significantly greater percentage of non-marketable cobs was due to the increased immaturity of corn with increasing number of cultivations (Table 4).

For the second seeding, there were no significant differences in marketable yield, cob diameter (39.1-41.0 $\mathrm{mm})$, cob length $(21.8-22.5 \mathrm{~cm})$, and undeveloped end (0.06-0.38 $\mathrm{cm}$ ) among the treatments (Table 5). 
Table 3. Effect of rotary hoeing at different crop growth stages on the marketable yields and cob characteristics of mid-season sweet corn 'July Gem' planted at the second seeding date in 1999 and 2000 (mean $\pm \mathrm{SE}$ ). ${ }^{\mathrm{z}}$

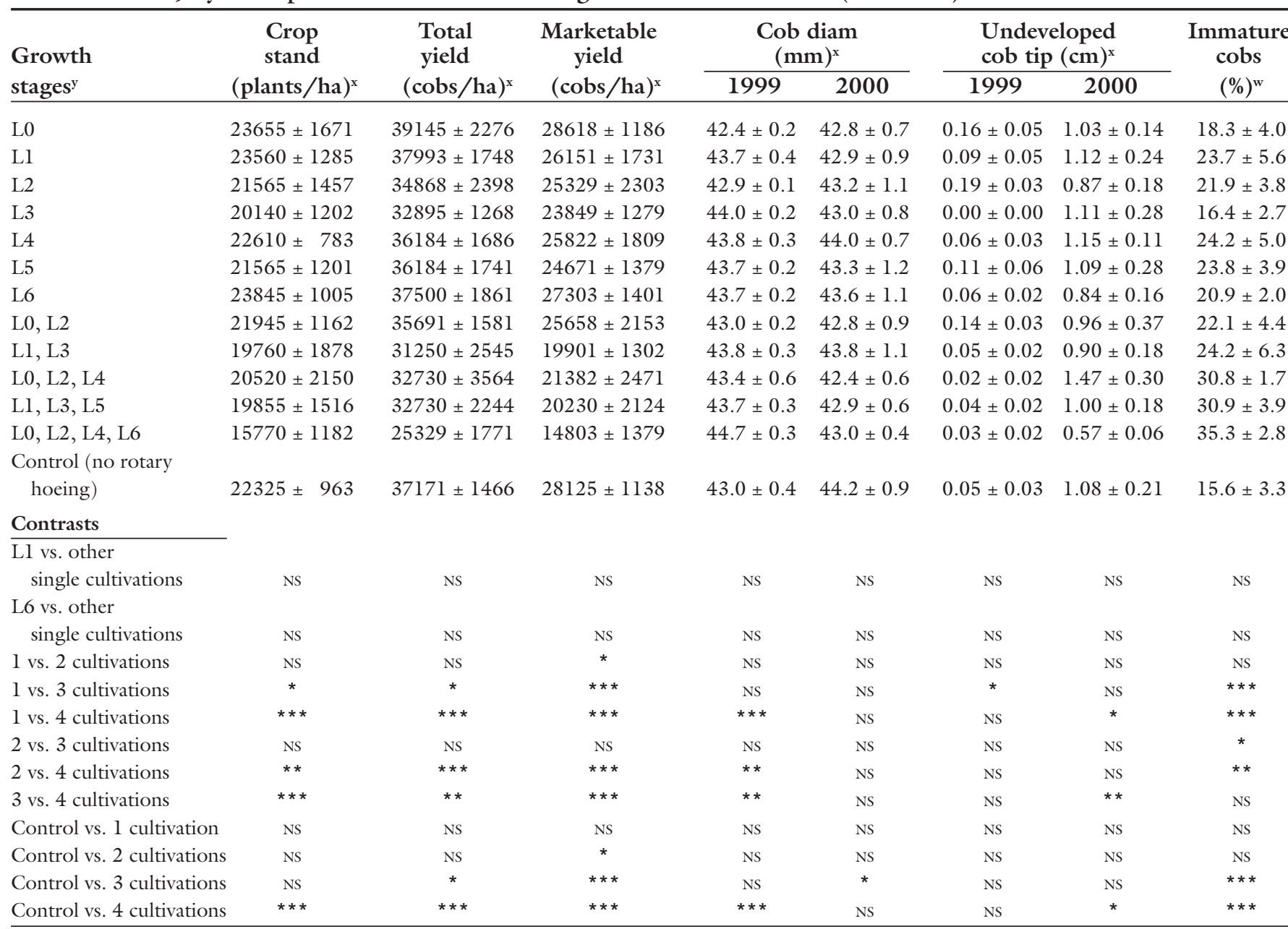

${ }^{2}$ Planting dates were 20 May 1999 and 23 May 2000. Data were pooled when variances were homogeneous and there were no significant interaction between years and treatments.

yCrop growth stages are designated L0 for the preemergence to L6 for the sixth-leaf stage.

${ }^{x} \mathrm{l}$ ha $=2.4711$ acres $; 1 \mathrm{~cm}=0.3937$ inch; $1 \mathrm{~mm}=0.0394$ inch.

wexpressed as percentage of total harvested cobs.

Ns,,,$* * * * *$ Nonsignificant or significant at $P \leq 0.05,0.01$, or 0.001 , respectively.

There was no significant difference in the percentage of immature cobs among treatments. The percentage of non-marketable cobs varied between $57 \%$ to $81 \%$ and was primarily due to insect damage. There was significantly less insect damage in sweet corn which had been cultivated three times than in those that had been cultivated once, twice, or not at all. Similar results were reported by Weber et al. (1990), who noted a reduction in cob infestation by corn borer in cultivated plots.

In summary, this research indicates that sweet corn cultivar and date of seeding influenced this crop susceptibility to rotary hoeing. Sweet corn can be cultivated once with the rotary hoe at any growth stage, from preemergence to sixth-leaf stage without a yield reduction. The percentage of marketable cobs decreased primarily due to an increase in the number of immature cobs when the rotary hoe was used more than twice for the later-seeded mid-season cultivar or late-season cultivar. This might partly be because any given experiment was harvested on a single date, and therefore the marketable yield might have been reduced due to the number of immature cobs. However, in a normal production system, producers harvest several times the same field and consequently, the number of immature cobs would be significantly less than in these experiments. Insects were a problem only for the late-season cultivar. It was observed that occurrence of insect damage on cobs tended to be less when corn was cultivated more than twice. The type and condition of soil could play an important role in the susceptibility of corn to cultivation with the rotary hoe. It was observed that risks of crop damage increased at early stages with dry light soils or heavy wet soil (Cloutier and Leblanc, 2003). Seeding in light soil should be as deep as possible in order to minimize the risks of damaging sweet corn. The rotary hoe could be an effective tool in controlling weeds in an integrated weed management approach or for organic sweet corn production since it cultivates both within and between the rows. The rotary hoe, which covers a large area in a short time, can be used at later growth stages, extending the time period during which it can be used without damaging the crop and reducing yield. 


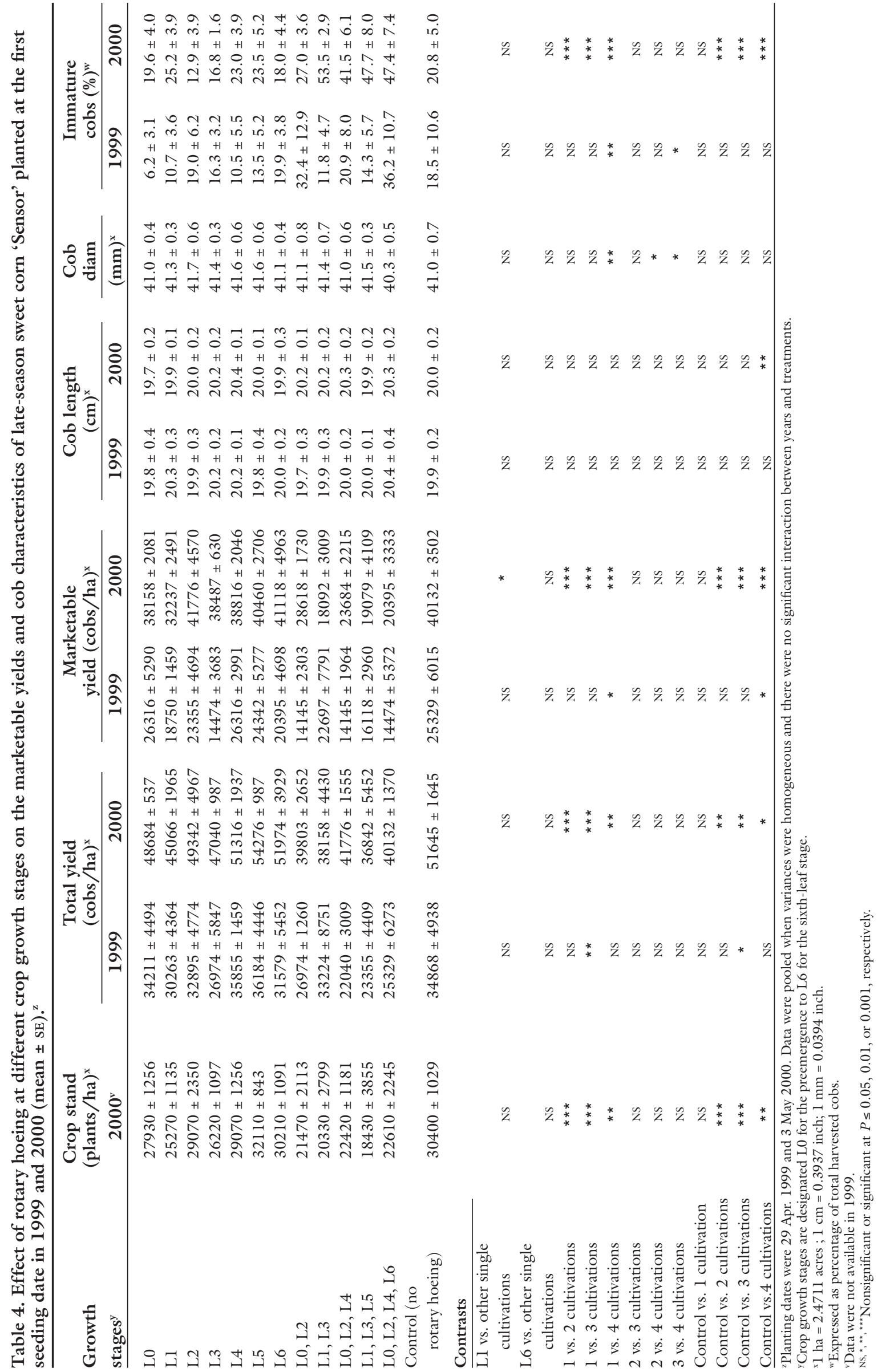


Table 5. Effect of rotary hoeing at different crop growth stages on the marketable yields and cob characteristics of late-season sweet corn 'Sensor' planted at the second seeding date in 1999 (mean $\pm \mathrm{SE}){ }^{\mathrm{z}}$

\begin{tabular}{|c|c|c|c|c|}
\hline $\begin{array}{l}\text { Growth } \\
\text { stages }^{y}\end{array}$ & $\begin{array}{c}\text { Crop } \\
\text { stand } \\
(\text { plants } / \text { ha })^{\mathrm{x}}\end{array}$ & $\begin{array}{c}\text { Total } \\
\text { yield } \\
(\text { cobs } / \mathrm{ha})^{\mathrm{x}}\end{array}$ & $\begin{array}{c}\text { Marketable } \\
\text { yield } \\
(\text { cobs } / \text { ha })^{x}\end{array}$ & $\begin{array}{c}\text { Insect } \\
\text { damage } \\
(\%)^{\mathrm{w}}\end{array}$ \\
\hline L0 & $18810 \pm 3663$ & $35856 \pm 4601$ & $10526 \pm 3798$ & $52.3 \pm 11.2$ \\
\hline Ll & $18050 \pm 2799$ & $34868 \pm 3418$ & $8553 \pm 1656$ & $49.5 \pm 8.6$ \\
\hline $\mathrm{L} 2$ & $16720 \pm 1551$ & $31579 \pm 2341$ & $5592 \pm 1554$ & $55.1 \pm 10.7$ \\
\hline L3 & $18050 \pm 2180$ & $30592 \pm 4208$ & $9539 \pm 3009$ & $36.4 \pm 3.7$ \\
\hline $\mathrm{L} 4$ & $18430 \pm 1623$ & $27961 \pm 5050$ & $9868 \pm 2182$ & $32.8 \pm 6.1$ \\
\hline L5 & $20900 \pm 1335$ & $37829 \pm 3056$ & $8224 \pm 1459$ & $54.5 \pm 6.5$ \\
\hline L6 & $21660 \pm 728$ & $39474 \pm 930$ & $10526 \pm 2791$ & $44.9 \pm 4.1$ \\
\hline L0, L2 & $22040 \pm 878$ & $41776 \pm 630$ & $11842 \pm 1699$ & $48.0 \pm 4.3$ \\
\hline $\mathrm{L} 1, \mathrm{~L} 3$ & $15390 \pm 1135$ & $29605 \pm 380$ & $10197 \pm 2706$ & $43.3 \pm 8.8$ \\
\hline $\mathrm{L} 0, \mathrm{~L} 2, \mathrm{~L} 4$ & $15580 \pm 2070$ & $30592 \pm 3997$ & $12829 \pm 1645$ & $30.2 \pm 4.1$ \\
\hline L1, L3, L5 & $15770 \pm 783$ & $26974 \pm 1741$ & $9868 \pm 1741$ & $30.2 \pm 5.0$ \\
\hline $\mathrm{L} 0, \mathrm{~L} 2, \mathrm{~L} 4, \mathrm{~L} 6$ & $14060 \pm 1298$ & $26974 \pm 2548$ & $9868 \pm 849$ & $41.8 \pm 4.2$ \\
\hline \multicolumn{5}{|l|}{ Control (no } \\
\hline rotary hoeing) & $21090 \pm 1897$ & $44079 \pm 4729$ & $13487 \pm 1245$ & $50.2 \pm 7.3$ \\
\hline
\end{tabular}

\section{Contrasts}

Ll vs. other single cultivations

L6 vs. other single cultivations

1 vs. 2 cultivations

1 vs. 3 cultivations

1 vs. 4 cultivations

2 vs. 3 cultivations

2 vs. 4 cultivations

3 vs. 4 cultivations

Control vs. 1 cultivation

Control vs. 2 cultivations

Control vs. 3 cultivations

Control vs. 4 cultivations

$\begin{array}{lccc}\text { NS } & \text { NS } & \text { NS } & \text { NS } \\ \text { NS } & \text { NS } & \text { NS } & \text { NS } \\ \text { NS } & \text { NS } & \text { NS } & \text { NS } \\ * & * & \text { NS } & * \\ * * & * & \text { NS } & \text { NS } \\ \text { NS } & * & \text { NS } & \text { NS } \\ * & * & \text { NS } & \text { NS } \\ \text { NS } & \text { NS } & \text { NS } & \text { NS } \\ \text { NS } & * * & & \text { NS } \\ \text { NS } & * & \text { NS } & \text { NS } \\ * * & * * * & \text { NS } & \text { NS } \\ * * & * * * & \text { NS }\end{array}$

${ }^{2}$ Planting date was 20 May 1999. Data were pooled when variances were homogeneous and there were no significant interaction between years and treatments.

${ }^{y}$ Crop growth stages are designated L0 for the preemergence to L6 for the sixth-leaf stage.

${ }^{\mathrm{x}} \mathrm{l} \mathrm{ha}=2.471 \mathrm{l}$ acres

"Expressed as percentage of total harvested cobs.

Ns, ${ }^{*}, * * * * *$ Nonsignificant or significant at $P \leq 0.05,0.01$, or 0.001 , respectively.

\section{Literature cited}

Bleiholder, H., T. Van den Boom, L. Buhr, C. Feller, H. Hack, M. Hess, R. Klose, P.D. Lancashire, U. Meier, P. Munger, R. Stauss, and E. Weber. 1997. Compendium of growth stage identification keys for mono- and dicotyledonous plants: Extended BBCH scale. 2nd ed. Novartis, Basel, Switzerland.

Canadian Food Inspection Agency. 1999. Fresh vegetable inspection manuals, Sweet corn. 3 July 2005. <http://www.inspection.gc.ca/english/plaveg/fresh/vegleg/ scornmais/scornmaise.shtml>. nique to predict weed emergence. Xième Colloque International sur la Biologie des Mauvaises Herbes à Dijon, Annales de l'Association Nationale pour la Protection des Plantes 10:3-6.

Colquhoun, J.B., R.R. Bellinder, and J.J. Kirkwyland. 1999. Efficacy of mechanical cultivation with and without herbicides in broccoli (Brassica oleracea), snap bean (Phaseolus vulgaris), and sweet corn (Zea mays). Weed Technol. 13:244-252.

Conseil des Productions Végétales du Québec Inc. 1994. Grilles de références en fertilisation. Publ. No. AGDEX 540. Conseil des Productions Végétales du Québec Inc., Québec, Que., Canada.

Giroux, I. 2002. Contamination de l'eau par les pesticides dans les régions de culture de maïs et de soya au Québec. Ministère de l'Environnement, Gouvernement du Québec, Québec, Que., Canada.

Gunsolus, J.L. 1990. Mechanical and cultural weed control in corn and soybeans. Amer. J. Alternative Agr. 5:114-119.

Lareau, J. 1997. Stratégie de gestion intégrée des mauvaises herbes dans le maïs sucré. Publ. No. VR 213, AGDEX 253/641. Conseil des Productions Végétales du Québec Inc., Québec, Que., Canada.

Leblanc, M.L. and D. Cloutier. 2001. Mechanical weed control in corn (Zea mays L.), p. 205-214. In: C.Vincent, B. Panneton, and F. Fleurat-Lessard (eds.). Physical control in plant protection. Springer-Verlag, Berlin and Institut National de la Recherche Agronomique, Paris.

Leblanc, M.L., G. Breton, D. Cloutier, J. Boisclair, G. Moreau, and J. Brodeur. 2003. Validation de techniques de lutte alternative contre les insectes et les mauvaises herbes dans le maïs sucré. Rapport final, Stratégie phytosanitaire-Saint-Laurent Vision 2000. Publ. No. IRDA-2-MSU-02-126. SaintHyacinthe, Que., Canada.

Smith, D., D.C. Cloutier, A. Mackenzie, T. Paulitz, B. Coulman, and K. Stewart. 1996. Développement d'un programme de lutte intégrée en vue d'éliminer les besoins d'herbicides dans la production de maïs. Rapport final. Publ. No. FRDT-E-PREE \#92-1. Ministère de l'Environnement du Québec, Que., Canada.

Statistics Canada. 2004. Fruit and vegetable production, February 2004. Catalogue No. 22-003-XIB, Vol. 72(2). Statistics Canada, Agriculture Division, Horticultural Crops Unit, Ottawa, Canada.

Weber, D.C., F.X. Mangan, D.N. Ferro, and H.V. Marsh, Jr. 1990. Effect of weed abundance of european corn borer (Lepidoptera: Pyralidae) infestation of sweet corn. Environ. Entomol. 19:1858-1865. 